\author{
CHRISTOPHER PETERSON, NANSOOK PARK and MARTIN \\ E.P. SELIGMAN
}

\title{
ORIENTATIONS TO HAPPINESS AND LIFE SATISFACTION: THE FULL LIFE VERSUS THE EMPTY LIFE
}

\begin{abstract}
Different orientations to happiness and their association with life satisfaction were investigated with 845 adults responding to Internet surveys. We measured life satisfaction and the endorsement of three different ways to be happy: through pleasure, through engagement, and through meaning. Each of these three orientations individually predicted life satisfaction. People simultaneously low on all three orientations reported especially low life satisfaction. These findings point the way toward a distinction between the full life and the empty life.
\end{abstract}

KEY WORDS: empty life, eudemonia, flow, full life, hedonism, life satisfaction, meaning

\section{INTRODUCTION}

Philosophers and psychologists have long been concerned with the good life and how it can be achieved (Guignon, 1999; Russell, $1930,1945)$. Often they propose a sovereign principle to be followed in order to be happy. So, the doctrine of hedonism maximizing pleasure and minimizing pain - was articulated thousands of years ago by Aristuppus (435-366 BCE) who championed immediate sensory gratification (Watson, 1895). Hedonism was elaborated by Epicurus (342-270 BCE) into the edict of ethical hedonism, which holds that our fundamental moral obligation is to maximize our experience of pleasure. Early Christian philosophers denounced hedonism as inconsistent with the goal of avoiding sin, but Renaissance philosophers such as Erasmus (1466-1536) and Thomas Moore (1478-1535) argued that it was God's wish that people be happy, so long as they did not become preoccupied with "artificial" ways of achieving pleasure. Later British philosophers like David Hume 
(1711-1776) and Jeremy Bentham (1748-1832) used the doctrine of hedonism to lay the foundation for utilitarianism, which was ushered into psychology as the underpinning of psychoanalysis and all but the most radical of the behaviorisms. Hedonism is alive and well today in the name of a new field - hedonic psychology (Kahneman et al., 1999). At least in the modern Western world, the pursuit of pleasure is widely endorsed as a way to achieve satisfaction: "Don't worry - be happy."

Standing in contrast to hedonism is another venerable tradition that can be traced to Aristotle's (384-322 BCE) notion of eudemonia - being true to one's inner self (demon). According to this view, true happiness entails identifying one's virtues, cultivating them, and living in accordance with them (Aristotle, 2000). Aristotle considered sensual pleasure as touted by the hedonists to be vulgar. Similar positions were advanced by John Stuart Mill (1806-1873) and Bertrand Russell (1872-1970) and undergird more modern psychological notions such as Rogers' (1951) ideal of the fully-functioning person, Maslow's (1970) concept of selfactualization, Ryff and Singer's (1996) vision of psychological well-being, and Deci and Ryan's (2000) self-determination theory. Uniting eudemonic emphases is the premise that people should develop what is best within themselves and then use these skills and talents in the service of greater goods - including in particular the welfare of other people or humankind writ large. Again, in the modern world, the pursuit of a meaningful life is widely endorsed as a way to achieve satisfaction: "Be all that you can be," and "Make a difference."

As implied, different psychological traditions have respectively addressed these two principles of achieving satisfaction. Often these traditions have proceeded independently from one another, with confusion introduced by the tendency of those working within each tradition to claim "happiness" as a label for their subject matter and to deny - if only implicitly - its use by those in the other camp ${ }^{1}$. Sometimes the debate becomes explicit, and we see investigators playing off the merits of pleasure and meaning as routes to the psychological good life (e.g., Compton et al., 1996; Waterman, 1993). Research suggests that both points of view can be supported by data (Ryan and Deci, 2000). 
We extend this line of work by simultaneously examining the pursuit of pleasure and the pursuit of meaning as different routes to happiness. The unique contribution of our research is to consider a third orientation to happiness: the pursuit of engagement (Seligman, 2002). Here we have been influenced by Csikszentmihalyi's (1990) writings on flow: the psychological state that accompanies highly engaging activities. Time passes quickly. Attention is focused on the activity. The sense of self is lost. The aftermath of the flow experience is invigorating.

In his studies of eudemonia, Waterman (1993) initially equated the flow state with eudemonia (which he termed personal expressiveness) but then concluded from his data that flow represented an "amalgam" of hedonic and eudemonic features. We suggest instead that flow is distinct. Flow is not the same as sensual pleasure. Indeed, flow is nonemotional and arguably nonconscious. People may describe flow as enjoyable, but this is an after-the fact summary judgment; "joy" is not immediately present during the activity itself. So, flow differs from hedonism, in which positive emotional experience is front-and-center (Csikszentmihalyi, 1999). At least at any given point in time, flow and pleasure may even be incompatible.

Although the pursuit of a meaningful life can at times produce flow for some individuals - e.g., those volunteering in a hospice or a soup kitchen - not all flow-producing activities are meaningful in the sense of connecting an individual to a greater good (consider playing bridge or Scrabble), and not all meaningful activities entail the total absorption that defines flow. For example, each of us does committee work at our university. At its best, this work is meaningful, but we have yet to lose ourselves in its performance.

We report here an empirical investigation of these three ways of being happy. The following questions guided our inquiry:

- Are these three orientations to happiness empirically distinguishable individual differences;

- Is an orientation to pleasure incompatible with an orientation to engagement, as implied by the characterization of the flow state as noncognitive and nonemotional, or is it possible for the same person to pursue these different ways of being happy; 
- Do these three orientations each contribute to life satisfaction, or are some more important than others; and

- Are there interactions between or among these orientations with respect to life satisfaction; that is, does their joint presence predict more life satisfaction than expected from the individual components, and, conversely, does their joint absence predict less than expected life satisfaction?

\section{METHOD}

\section{Participants}

Research participants were two groups of adult volunteers who completed measures on-line. During initial instrument development, 180 respondents participated, and for the main study, 845 respondents participated. Demographic characteristics of these two samples are summarized in Table I.

\section{Measures}

Orientations to Happiness

To develop the Orientations to Happiness measure used in this study, 12 face-valid items reflecting each of the three orientations were initially drafted by the authors and refined in a focus group of college students $(n=15)$ enrolled in a positive psychology class at the University of Pennsylvania. Each item required a respondent to answer on a 5-point scale the degree to which the item applied (" 1 = very much unlike me" through " 5 = very much like me"). Items tapping pleasure and meaning resemble those used in previous research contrasting hedonic versus eudemonic orientations (cf. King and Napa, 1998; McGregor and Little, 1998). Items measuring engagement were based on Csikszentmihalyi's (1990) characterization of the flow state as self-less absorption in ongoing activity.

Along with demographic questions, the initial 36-item Orientations to Happiness measure was placed on the Internet and completed by participants in the instrument development sample $(n=180)$. Internal consistencies of the three subscales formed by averaging the respective items, were satisfactory (pleasure $\alpha=0.84$, flow $\alpha=0.77$, and meaning $\alpha=0.88$ ) and exceeded the 
TABLE I

Demographic characteristics of samples

\begin{tabular}{|c|c|c|}
\hline & $\begin{array}{l}\text { Instrument } \\
\text { development } \\
\text { sample }(n=180)(\%)\end{array}$ & $\begin{array}{l}\text { Main sample } \\
(n=845)(\%)\end{array}$ \\
\hline \multicolumn{3}{|l|}{ Age (years) } \\
\hline $18-20$ & 27 & 15 \\
\hline $21-24$ & 15 & 10 \\
\hline $25-34$ & 18 & 19 \\
\hline $35-44$ & 17 & 21 \\
\hline $45-54$ & 16 & 24 \\
\hline $55-64$ & 6 & 8 \\
\hline $65+$ & 1 & 3 \\
\hline \multicolumn{3}{|l|}{ Gender } \\
\hline Male & 38 & 28 \\
\hline Female & 62 & 72 \\
\hline \multicolumn{3}{|l|}{ Education } \\
\hline$<$ High school & 1 & 1 \\
\hline High school graduate & 5 & 9 \\
\hline Some college & 44 & 31 \\
\hline Associates degree & 5 & 6 \\
\hline Baccalaureate & 17 & 24 \\
\hline$>$ Baccalaureate & 28 & 29 \\
\hline \multicolumn{3}{|l|}{ Marital status } \\
\hline Married/living as & 31 & 45 \\
\hline Single & 58 & 39 \\
\hline Widowed & 1 & 1 \\
\hline Divorced & 10 & 15 \\
\hline \multicolumn{3}{|l|}{ Ethnicity } \\
\hline African American & 4 & 3 \\
\hline Asian American & 3 & 3 \\
\hline Latino/a & 3 & 2 \\
\hline White & 82 & 86 \\
\hline Other & 8 & 6 \\
\hline U.S. citizen & 76 & 85 \\
\hline \multicolumn{3}{|l|}{ Town of residence } \\
\hline Farm & 1 & 1 \\
\hline Country & 6 & 12 \\
\hline Suburban & 19 & 26 \\
\hline Small city $(<50 \mathrm{~K})$ & 16 & 17 \\
\hline Medium city $(<100 \mathrm{~K})$ & 15 & 15 \\
\hline
\end{tabular}


Table I. (Continued)

\begin{tabular}{lll}
\hline & $\begin{array}{l}\text { Instrument } \\
\text { development } \\
\text { sample }(n=180)(\%)\end{array}$ & $\begin{array}{l}\text { Main sample } \\
(n=845)(\%)\end{array}$ \\
\hline $\begin{array}{l}\text { Large city }(<500 \mathrm{~K}) \\
\text { Very large city }(>500 \mathrm{~K})\end{array}$ & 16 & 16 \\
$\begin{array}{l}\text { Political leaning } \\
(1=\text { liberal, }\end{array}$ & 27 & 13 \\
$7=$ conservative $)$ & $M=3.55$ & $M=3.37$ \\
\hline
\end{tabular}

subscale intercorrelations, which nonetheless were of moderate magnitude (mean $r=0.51$ ). These results suggested that the three orientations to happiness are distinguishable but related.

To sharpen the distinctions among the subscales, the six items in each subscale with the highest item-total correlations were chosen, and a revised 18-item measure was created and placed online along with demographic questions to be completed by participants in the main study $(n=845)$. The revised version of this scale is presented in Table II. Subscale means were calculated by averaging the relevant items.

Satisfaction With Life Scale (SWLS) (Diener et al., 1985)

The SWLS consists of five items which measure the individual's evaluation of satisfaction with life in general (e.g., "I am satisfied with my life," and "If I could live my life over, I would change almost nothing"). Respondents select one of seven options (ranging from "strongly disagree" to "strongly agree") for each question. Responses were averaged to provide a total life satisfaction score. Research has established acceptable psychometric properties for the SWLS (Diener, 1994). In the current study, the SWLS was skewed toward the right, meaning that most respondents were relatively happy (cf. Diener and Diener, 1996; Myers and Diener, 1995).

\section{Procedure}

All measures were placed online at www.positivepsychology.org/ strengths along with demographic questions (age; gender; 
TABLE II

Orientations to happiness subscale items and factor loadings $(n=845)$

\begin{tabular}{|c|c|c|c|}
\hline $\begin{array}{l}\text { Eigenvalue } \\
\% \text { of variance }\end{array}$ & $\begin{array}{l}\text { Factor } 1 \\
4.96 \\
28\end{array}$ & $\begin{array}{l}\text { Factor } 2 \\
2.80 \\
16\end{array}$ & $\begin{array}{l}\text { Factor } 3 \\
1.60 \\
9\end{array}$ \\
\hline \multicolumn{4}{|l|}{ Life of meaning } \\
\hline $\begin{array}{l}\text { 02. My life serves a } \\
\text { higher purpose. }\end{array}$ & 0.75 & 0.01 & 0.08 \\
\hline $\begin{array}{l}\text { 05. In choosing what to do, } \\
\text { I always take into account } \\
\text { whether it will benefit } \\
\text { other people. }\end{array}$ & 0.54 & 0.01 & 0.32 \\
\hline $\begin{array}{l}\text { 11. I have a responsibility } \\
\text { to make the world a better place. }\end{array}$ & 0.79 & -0.01 & 0.05 \\
\hline 12. My life has a lasting meaning. & 0.82 & 0.01 & 0.17 \\
\hline 14. What I do matters to society. & 0.73 & 0.01 & 0.11 \\
\hline $\begin{array}{l}\text { 17. I have spent a lot of time } \\
\text { thinking about what life means } \\
\text { and how I fit into its big picture. }\end{array}$ & 0.57 & 0.11 & 0.01 \\
\hline \multicolumn{4}{|l|}{ Life of pleasure } \\
\hline $\begin{array}{l}\text { 03. Life is too short to postpone } \\
\text { the pleasures it can provide. }\end{array}$ & 0.22 & 0.68 & 0.12 \\
\hline $\begin{array}{l}\text { 08. I go out of my way } \\
\text { to feel euphoric. }\end{array}$ & 0.12 & 0.60 & 0.36 \\
\hline $\begin{array}{l}\text { 13. In choosing what to do, } \\
\text { I always take into account } \\
\text { whether it will be pleasurable. }\end{array}$ & 0.00 & 0.75 & 0.01 \\
\hline $\begin{array}{l}\text { 15. I agree with this statement: } \\
\text { "Life is short - eat dessert first." }\end{array}$ & -0.01 & 0.71 & -0.01 \\
\hline $\begin{array}{l}\text { 16. I love to do things } \\
\text { that excite my senses. }\end{array}$ & 0.16 & 0.74 & 0.01 \\
\hline $\begin{array}{l}\text { 18. For me, the good life } \\
\text { is the pleasurable life. }\end{array}$ & -0.01 & 0.79 & 0.00 \\
\hline \multicolumn{4}{|l|}{ Life of engagement } \\
\hline $\begin{array}{l}\text { 01. Regardless of what I } \\
\text { am doing, time passes } \\
\text { very quickly. }\end{array}$ & 0.23 & 0.00 & 0.48 \\
\hline $\begin{array}{l}\text { 04. I seek out situations } \\
\text { that challenge my } \\
\text { skills and abilities. }\end{array}$ & 0.40 & 0.12 & 0.51 \\
\hline $\begin{array}{l}\text { 06. Whether at work or } \\
\text { play, I am usually "in a zone" } \\
\text { and not conscious of myself. }\end{array}$ & 0.00 & 0.01 & 0.75 \\
\hline
\end{tabular}


Table II. (Continued)

\begin{tabular}{llll}
\hline Eigenvalue & $\begin{array}{l}\text { Factor } 1 \\
4.96\end{array}$ & $\begin{array}{l}\text { Factor 2 } \\
2.80\end{array}$ & $\begin{array}{l}\text { Factor 3 } \\
1.60\end{array}$ \\
$\begin{array}{l}\text { \% of variance } \\
28\end{array}$ & 0.13 & 0.01 & $\mathbf{0 . 7 8}$ \\
\hline $\begin{array}{l}\text { 07. I am always very } \\
\text { absorbed in what I do. }\end{array}$ & 0.16 & 0.41 & $\mathbf{0 . 4 9}$ \\
$\begin{array}{l}\text { 09. In choosing what to } \\
\text { do, I always take into account } \\
\quad \text { whether I can lose myself in it. }\end{array}$ & 0.12 & 0.00 & $\mathbf{0 . 6 1}$ \\
$\begin{array}{l}\text { 10. I am rarely distracted by } \\
\text { what is going on around me. }\end{array}$ & & & \\
\hline
\end{tabular}

Note: Numbers in front of items correspond to order in the final Orientations to Happiness measure. Entries in bold represent the factor on which item loaded most highly.

education; marital status; ethnicity; U.S. citizenship; size of one's town of residence, from $1=$ farm through $7=$ very large city; and liberal-versus-conservative political leaning assessed by a single 7point scale, from $1=$ liberal to $7=$ conservative). On the first page of the web site, a short description of the study including its purpose and its approximate time commitment was provided.

This web site also includes other psychological measures and provides individualized feedback about an individual's top scores on these other measures upon completion of all measures (feedback on the Orientations to Happiness measure was not provided). The feedback feature is apparently attractive to potential respondents and may explain why we did not need to advertise the survey. To preserve respondent anonymity, we did not track how individuals came across our survey on the Internet. They may have learned about it by following a link on the Positive Psychology Webpage, by following links on other webpages, or by hearing about it from previous respondents or from our media interviews.

According to a recent study of Internet users by the UCLA Center for Communication Policy (Lebo, 2003), more than 70\% of Americans use the Internet. Although certain limitations exist, Internet surveys provide researchers with the opportunities to recruit efficiently large and diverse samples at relatively little cost (Birnbaum, 2000, 2004; Kraut et al., 2004; Schonlau et al., 2002). 


\section{RESULTS}

For the main sample $(n=845)$, a principal components analysis of the 18 items in the revised Orientations to Happiness measure, using varimax rotation, provided strong support for the a priori assumption that it assessed three different orientations to the good life. Three factors were identified with eigen-values greater than 1.00, and each of the 18 items loaded most strongly on a factor along with the other items intended to assess the same orientation (Table II). Consistent with this analysis, internal consistencies of the three subscales were satisfactory and exceeded the scale intercorrelations (Table III). Subscale means, created by averaging the appropriate items, could range from 1 to 5. Each had a slight skew. Nevertheless, each subscale yielded a range of scores.

There were no significant demographic variations in life satisfaction other than being married (Table III). However, several

TABLE III

Intercorrelations among measures $(n=845)$

Pleasure Engagement Meaning Life

satisfaction

\begin{tabular}{|c|c|c|c|c|}
\hline Pleasure & - & & & \\
\hline Engagement & $0.31 *$ & - & & \\
\hline Meaning & $0.18^{*}$ & $0.46^{*}$ & - & \\
\hline Life satisfaction & $0.17^{*}$ & $0.30^{*}$ & $0.26^{*}$ & - \\
\hline Age & $-0.22 *$ & 0.07 & 0.00 & -0.09 \\
\hline Gender $(1=$ male, $2=$ female $)$ & 0.09 & -0.06 & -0.03 & 0.06 \\
\hline $\begin{array}{l}\text { Politics }(1=\text { conservative, } \\
\quad 7=\text { liberal })\end{array}$ & -0.02 & -0.08 & -0.10 & -0.05 \\
\hline Education & $-0.19^{*}$ & 0.05 & 0.08 & -0.01 \\
\hline Married $(0=$ no, $1=$ yes $)$ & $-0.17 *$ & 0.01 & -0.03 & $0.17 *$ \\
\hline Home town size & 0.07 & 0.05 & 0.05 & -0.05 \\
\hline White $(0=$ no, $1=$ yes $)$ & -0.07 & -0.11 & $-0.18^{*}$ & -0.06 \\
\hline U.S. citizen $(0=$ no, $1=$ yes $)$ & -0.03 & -0.10 & -0.08 & 0.01 \\
\hline$M$ & 3.20 & 3.05 & 3.42 & 4.93 \\
\hline SD & 0.84 & 0.72 & 0.88 & 1.37 \\
\hline$\alpha$ & 0.82 & 0.72 & 0.82 & 0.90 \\
\hline Skew & -0.09 & 0.08 & -0.32 & -0.73 \\
\hline
\end{tabular}

$* p<0.001$. 
modest demographic correlates of the Orientations to Happiness subscales were found. Those who were younger, less educated, or unmarried were somewhat higher in their endorsement of an orientation to pleasure - as Aristotle might have predicted. Ethnic minorities, chiefly African Americans and Asian Americans, scored somewhat higher than Whites on orientation to meaning.

Considered individually, each of the orientations to happiness predicted life satisfaction, from small (pleasure) to moderate (engagement, meaning) degrees (Table III). A hierarchical multiple regression predicting life satisfaction was then computed

TABLE IV

Hierarchical multiple regression predicting life satisfaction $(n=845)$

\begin{tabular}{ll}
\hline & $\beta$ \\
\hline Step 1 & $-0.17^{*}$ \\
Age & 0.01 \\
Education & $0.08^{* *}$ \\
Gender $(1=$ male, $2=$ female $)$ & -0.05 \\
Politics $(1=$ conservative, $7=$ liberal $)$ & -0.06 \\
Home town size & 0.02 \\
U.S. citizen $(0=$ no, $1=$ yes $)$ & $0.24^{*}$ \\
Married $(0=$ no, $1=$ yes $)$ & -0.01 \\
White $(0=$ no, $1=$ yes $)$ & $R^{2}=0.066^{* *}$ \\
& \\
Step 2 & $-0.11^{* *}$ \\
Pleasure & $-0.24^{*}$ \\
Engagement & $-0.17^{*}$ \\
Meaning & $\Delta R^{2}=0.116^{*}$ \\
& \\
Step 3 & -0.04 \\
Pleasure $\times$ engagement & -0.03 \\
Pleasure $\times$ meaning & 0.00 \\
Meaning $\times$ engagement & $\Delta R^{2}=0.004$ \\
Step 4 & $-2.50 * *$ \\
Pleasure $\times$ engagement $\times$ meaning & $\Delta R^{2}=0.006^{* *}$ \\
&
\end{tabular}

Note: Predictors in steps 1 and 2 were normalized (see text). $\beta$ weights are for the final model.

$* p<0.001 ; * * p<0.05$. 
(Table IV), entering in the first step the demographic variables (age, education, gender $[1=$ male, $2=$ female $]$, marital status [married $=1$ or not $=0]$, politics $[1=$ conservative, $7=$ liberal], US citizenship [yes $=1$ or no $=1$ ], size of home town $[1=$ farm, $7=$ very large city], and ethnicity [White $=1$ versus not $=0]$ ), in the second step by the subscales measuring the three orientations to happiness, in the third step the two-way product terms between the orientations (i.e., all possible pairs of three orientations), and in the last step the three-way product (pleasure $\times$ engagement $\times$ meaning).

Following the guidelines of Aiken and West (1991), we centered the predictors in the first two blocks by normalizing them and computed interactions by multiplying the relevant normalized scores, but we did not center these product terms or the criterion. Multicollinearity diagnostics were well within acceptable limits. The overall regression was significant $\left(R^{2}=0.19, F[15,829]=13.15, p<0.001\right)$. Above and beyond the influence of demographic variables, the "main" effects of the three orientations (all of which were significant predictors in the final model), and the two-way interactions (none of which was statistically significant), the three-way interaction - entered in the last step - was statistically significant, although small in its absolute effect.

We therefore limited our attention to the three-way interaction. To interpret it, we grouped the respondents in various ways on each of the three subscales (e.g., low versus high, low versus medium versus high, quartiles, quintiles, deciles, and so on) and graphed life satisfaction scores as a joint function of these groupings. No matter how we grouped the respondents, the same patterns emerged: (a) somewhat higher life satisfaction scores for respondents simultaneously near the top of all three Orientations to Happiness subscales; and (b) notably lower life satisfaction scores for respondents simultaneously near the bottom of all three subscales. Figure 1 is a representative composite, where respondents simultaneously low on all three orientations (who have what might be called the "Empty Life") reported the least life satisfaction, whereas those simultaneously high on all three orientations (who have what can be identified as the "Full Life") reported the greatest life satisfaction. 


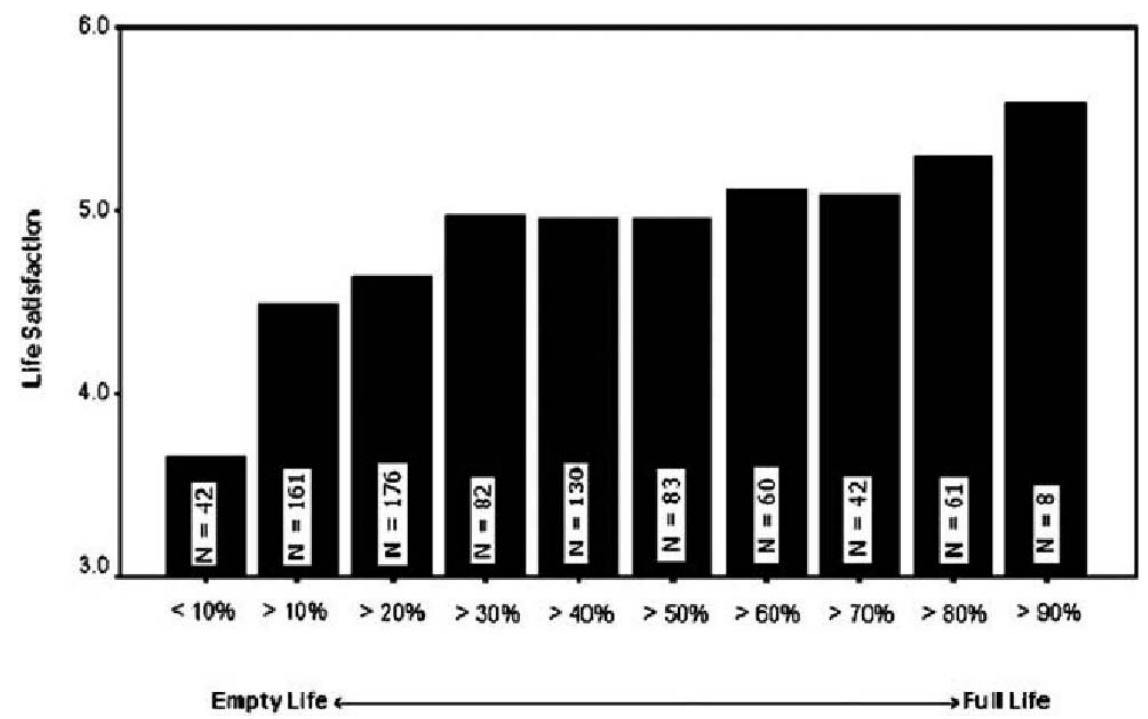

Figure 1. Mean life satisfaction scores along the continuum of the empty life versus the full life. Groups were created by identifying respondents simultaneously in the top $90 \%$ of each of the three subscales, simultaneously in the top $80 \%$ of each, and so on.

\section{DISCUSSION}

Drawing on past theory and research, we distinguished three possible orientations to happiness (Seligman, 2002). The present study found that these orientations are distinguishable, that they are not incompatible and thus able to be pursued simultaneously, and that each is individually associated with life satisfaction. As previous research has shown, either hedonism or eudemonia can accompany a satisfying life, and so too can engagement.

Our interest was in people's endorsement of these orientations to happiness, and we did not ascertain whether those who said they believe in pursuing pleasure actually have more sensually gratifying experiences than those who do not, whether those who supported engagement as an orientation to happiness more frequently lose themselves in highly absorbing activities, or whether those who agreed with items reflecting a life of meaning are more likely to perform service to others. We intend to pursue such questions in further research, using a version of Waterman's 
(1993) procedure that asks respondents to report on "activities of importance" and their features.

We also intend to study these orientations and their relationship to life satisfaction over time. We assume that given orientations shape conduct and thereby produce more or less happiness, but the cross-sectional design of the present study does not allow this notion to be tested. In particular, we need to investigate the alternative interpretation of our data that a satisfying life leads to a diverse behavioral repertoire that includes pleasurable, engaging, and meaningful activities (cf. Fredrickson, 2001). Although only trends in the present sample, we found it interesting that the respondents with the fullest life were more likely than those in other groups to be older, to be married, and to be more highly educated - all factors that arguably open doors to diverse and satisfying experiences.

The present research nonetheless extends theory in several ways, suggesting in particular that an orientation to engagement differs from orientations to pleasure or to meaning. Also, an orientation to pleasure is not as strong an individual predictor of life satisfaction as orientations to engagement or to meaning. But neither is pleasure irrelevant to life satisfaction, because it represents value added to a life rich in engagement and meaning and value subtracted from a life deficient in these respects. The Full Life as we have defined it predicts life satisfaction somewhat beyond the sum of its parts, and the Empty Life predicts notably less.

Many psychologists who study pleasure seem unconvinced that it can be increased, positing a genetically influenced set point of affectivity to which most of us return following hedonically laden experiences, either good or bad (Brickman and Campbell, 1971; Kahneman, 1999). Perhaps the immutability of our ability to experience pleasure explains why its pursuit can be futile (Csikszentmihalyi, 1999). In contrast, a life of engagement seems more under deliberate control (Massimini and Delle Fave, 2000), as does a life of meaning (Frankl, 1963). As positive psychology turns its attention to interventions that cultivate the good life, perhaps interventions that target engagement and meaning will prove most fruitful (Linley and Joseph, in press). However, we would not want to rule out all attempts to increase pleasure, and perhaps the way to boost pleasure is to follow one implication 
of the present results that pleasure-enhancing techniques like savoring be incorporated into those that increase engagement and meaning (Linville and Fischer, 1991). Perhaps increased pleasure can occur as a happy by-product of such interventions.

Besides our cross-sectional design, let us note an additional limitation of our research, specifically our strategy of obtaining research participants. Although increasingly common in psychological research, samples obtained from the World Wide Web are often criticized because of the special characteristics of respondents. Individuals need to have access to a computer and the ability to use it. They need to be interested enough to spend time answering questions. But contrast our web sample with those obtained from typical psychology subject pools and ask which provides a sounder basis for generalization. Our respondents ranged across the adult years and different levels of formal education. Men and women were represented. Many were married. They lived in all parts of the United States or came from many different countries. Our main sample included more than 100 (14\%) non-White respondents. Respondents fell at all points along the conservative-liberal political spectrum. Without belaboring the point, we observe that Internet samples are at least as diverse as those recruited from psychology subject pool samples at colleges or universities (Birnbaum, 2000, 2004; Kraut et al., 2004; Lebo, 2003; Lenhart, 2000; Schonlau et al., 2002).

Many of the individuals who simultaneously scored low on all three orientations were likely depressed, anxious, or otherwise distressed. These are the people that clinical psychology has studied for 50 years, grouping everyone else together as "normal" (Seligman and Csikszentmihalyi, 2000). We suggest that a distinction can be made along the continuum from the mere normal to the supernormal. Investigating those people who have particularly high life satisfaction may well reveal ways of improving the well-being of all of us (Diener and Seligman, 2002).

\section{ACKNOWLEDGEMENTS}

We acknowledge the support of the Manuel D. and Rhoda Mayerson Foundation in creating the Values in Action Institute, 
a nonprofit organization dedicated to the development of a scientific knowledge base of human strengths. Address correspondence to Christopher Peterson, Department of Psychology, University of Michigan, 525 East University, Ann Arbor, MI 48109-1109; chrispet@umich.edu.

\section{NOTES}

1 In the present paper, we use "happiness" in its broadest sense to include hedonic features but also fulfillment and contentment (cf. Myers, 1992; Seligman, 2002). We follow Diener's (1984) lead in defining "life satisfaction" as a summary appraisal of the quality of one's life regardless of how it is achieved (cf. Pavot and Diener, 1993).

\section{REFERENCES}

Aiken, L.S. and S.G. West: 1991, Multiple Regression: Testing and Interpreting Interactions (Sage, Thousand Oaks, CA).

Aristotle: 2000, Nicomachean Ethics (R. Crisp, Trans.) (Cambridge University Press, Cambridge, England).

Birnbaum, M.H. (ed.): 2000, Psychological Experiments on the Internet (Academic Press, San Diego).

Birnbaum, M.H.: 2004, 'Human research and data collection via the Internet', Annual Review of Psychology 55, pp. 803-832.

Brickman, P. and D.T. Campbell: 1971, 'Hedonic relativism and planning the good society', in M.H. Appley (ed.), Adaptation-Level Theory (Academic Press, New York), pp. 287-305.

Compton, W.C., M.L. Smith, K.A. Cornish and D.L. Qualls: 1996, 'Factor structure of mental health measures', Journal of Personality and Social Psychology 71, pp. 406-413.

Csikszentmihalyi, M.: 1990, Flow: The Psychology of Optimal Experience (HarperCollins, New York).

Csikszentmihalyi, M.: 1999, 'If we are so rich, why aren't we happy?', American Psychologist 54, pp. 821-827.

Deci, E.L. and R.M. Ryan: 2000, "The "what" and "why" of goal pursuits: Human needs and the self-determination of behavior', Psychological Inquiry 11, pp. 227-268.

Diener, E.: 1984, 'Subjective well-being', Psychological Bulletin 95, pp. 542575.

Diener, E.: 1994, 'Assessing subjective well-being: Progress and opportunities', Social Indicators Research 31, pp. 103-157.

Diener, E. and C. Diener: 1996, 'Most people are happy', Psychological Science 7, pp. 181-185. 
Diener, E. and M.E.P. Seligman: 2002, 'Very happy people', Psychological Science 13, pp. 80-83.

Diener, E., R.A. Emmons, R.J. Larsen and S. Griffin: 1985, 'The satisfaction with life scale', Journal of Personality Assessment 49, pp. 71-75.

Frankl, V.E.: 1963, Man's Search for Meaning: An Introduction to Logotherapy (Washington Square Press, New York).

Fredrickson, B.L.: 2001, 'The role of positive emotions in positive psychology: The broaden-and-build theory of positive emotions', American Psychologist 56 , pp. $218-226$.

Guignon, C. (ed.): 1999, The Good Life (Hackett, Indianapolis, IN).

Kahneman, D.: 1999, 'Objective happiness', in D. Kahneman, E. Diener and N. Schwarz (eds), Well-being: The Foundations of Hedonic Psychology (Russell Sage, New York), pp. 3-25.

Kahneman, D., E. Diener and N. Schwarz (eds): 1999, Well-being: The Foundations of Hedonic Psychology (Russell Sage, New York).

King, L.A. and C.K. Napa: 1998, 'What makes life good?', Journal of Personality and Social Psychology 75, pp. 156-165.

Kraut, R., J. Olson, M. Banaji, A. Bruckman, J. Cohen and M. Couper: 2004, 'Psychological research online: Report of Board of Scientific Affairs' Advisory Group on the Conduct of Research on the Internet', American Psychologist 59, pp. 105-117.

Lebo, H.: 2003, The UCLA Internet Report: Surveying the Digital Future-YearThree (University of California Regents, Los Angeles), Retrieved July 31, 2003, from http://www.ccp.ucla.edu/UCLA-Internet-Report-Year-Three. pdf.

Lenhart, A.: 2000, Who's Not Online: 57\% of Those Without Internet Access Say They Do Not Plan to Log on (Pew Internet \& American Life Project, Washington, DC), Retrieved July 31, 2003, from http://www.pewinternet.org/reports/toc.asp?Report_21.

Linley, P.A. and S. Joseph (eds): in press, Positive Psychology in Practice (John Wiley and Sons, New York).

Linville, P.W. and G.W. Fischer: 1991, 'Preferences for separating or combining events', Journal of Personality and Social Psychology 60, pp. 523.

Maslow, A.H.: 1970, Motivation and Personality (2nd ed) (Harper \& Row, New York).

Massimini, F. and A. Delle Fave: 2000, 'Individual development in a biocultural perspective', American Psychologist 55, pp. 24-33.

McGregor, I. and B.R. Little: 1998, 'Personal projects, happiness, and meaning: On doing well and being yourself', Journal of Personality and Social Psychology 74, pp. 494-512.

Myers, D.G.: 1992, The Pursuit of Happiness: Who is Happy - and Why (William Morrow, New York).

Myers, D.G. and E. Diener: 1995, 'Who is happy?', Psychological Science 6, pp. $10-19$. 
Pavot, W. and E. Diener: 1993, 'Review of the satisfaction with life scale', Psychological Assessment 5, pp. 164-172.

Rogers, C.R.: 1951, Client-Centered Therapy: Its Current Practice, Implications, and Theory (Houghton Mifflin, Boston).

Russell, B.: 1930, The Conquest of Happiness (Liveright, New York).

Russell, B.: 1945, A History of Western Philosophy, and Its Connection With Political and Social Circumstances from the Earliest Times to the Present Day (Simon \& Schuster, New York).

Ryan, R.M. and E.L. Deci: 2000, 'On happiness and human potentials: A review of research on hedonic and eudaimonic well-being', Annual Review of Psychology 52, pp. 141-166.

Ryff, C.D. and B. Singer: 1996, 'Psychological well-being: Meaning, measurement, and implications for psychotherapy research', Psychotherapy and Psychosomatics 65, pp. 14-23.

Schonlau, M., R.D. Fricker and M.N. Elliott: 2002, Conducting Research Surveys via E-mail and the Web (RAND, Santa Monica, CA).

Seligman, M.E.P.: 2002, Authentic Happiness (Free Press, New York).

Seligman, M.E.P. and M. Csikszentmihalyi: 2000, 'Positive psychology: An introduction', American Psychologist 55, pp. 5-14.

Waterman, A.S.: 1993, 'Two conceptions of happiness: Contrasts of personal expressiveness (eudaimonia) and hedonic enjoyment', Journal of Personality and Social Psychology 64, pp. 678-691.

Watson, J.: 1895, Hedonistic Theories from Aristippus to Spencer (Macmillan, New York).

Address for Correspondence:

CHRISTOPHER PETERSON

Department of Psychology

University of Michigan

525 East University

Ann Arbor, MI 48109-1109

U.S.A

E-mail: chrispet@umich.edu 